Article

\title{
Interdependences between Smallholder Farming and Environmental Management in Rural Malawi: A Case of Agriculture-Induced Environmental Degradation in Malingunde Extension Planning Area (EPA)
}

\author{
Kondwani G. Munthali * and Yuji Murayama \\ Division of Spatial Information Science, Graduate School of Life and Environmental Sciences, \\ University of Tsukuba, Tennoudai 1-1-1, Tsukuba, Ibaraki 305-8572, Japan; \\ E-Mail: mura@geoenv.tsukuba.ac.jp
}

* Author to whom correspondence should be addressed; E-Mail: kmunthali@gmail.com; Tel./Fax: +81-29-853-421.

Received: 14 February 2013; in revised form: 13 March 2013 / Accepted: 18 March 2013 / Published: 10 April 2013

\begin{abstract}
The objective of this article was to develop a deeper understanding of the interdependences between smallholder farming and the state of environmental management in rural Malawi. We examined the agricultural local governance framework in Malingunde Extension Planning Area (EPA), its contribution to food security and how it conflicts with overall land and forest resources management. The charcoal production process was discussed in line with its implications for agricultural production and environmental sustainability. The smallholder households employ inappropriate land management practices, engage in agricultural production on unsuitable land and use fertile soils, timber and firewood for brick production and construction and secondly engage in charcoal production (deforestation) as a coping mechanism against food deficiency. However, while detrimental in its own right, this environmental degradation in the area cannot be explicitly pinned to, for instance, the total charcoal supply being out of balance with wood stocks or insufficient land. It is, rather, usually due to failures to provide incentives to manage land and forest resources in a manner that allows regeneration of both the soils and wood stocks in the area. An improvement in the quality and quantity of the smallholder agriculture sector production would promote significantly the environmental management efforts.
\end{abstract}

Keywords: smallholder farming; environmental management; land management; agriculture 


\section{Introduction}

The agricultural sector in Malawi is categorized into the estate agriculture sector and the smallholder sector, with the latter accounting for $60 \%$ of agriculture gross domestic product (GDP) [1]. The smallholder sector employs over $85 \%$ of the rural population, contributing between 35 and $40 \%$ of total GDP and over $90 \%$ of total export earnings [2]. With the majority of the population (>80\%) living in rural areas in Malawi, both wage employment and the chances of escaping poverty are as such based on the success of the smallholder agriculture sector, which are currently very limited [3]. Coupled with high population growth, the pressure exerted on land and natural resources is enormous. As such, both customary land and protected forest areas are overexploited, worsening the state of the environment in the form of land degradation and forest cover loss. The resulting negative consequences include climate change, biodiversity loss, reduced timber supply, flooding, siltation and soil quality degradation [4].

Figure 1. The study site: Malingunde Extension Planning Area (EPA), Lilongwe, Malawi.

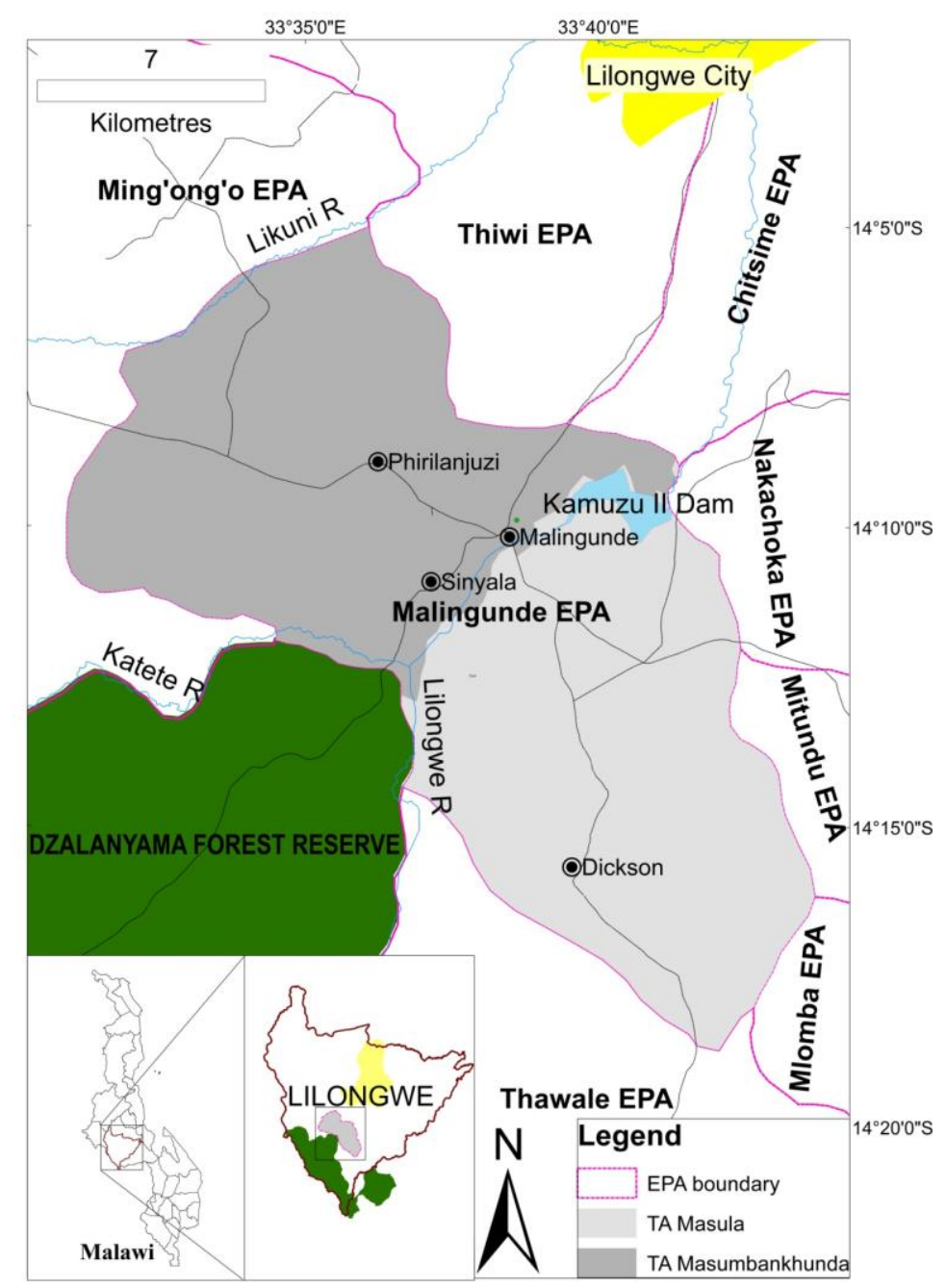

Smallholder farmers in Malawi experience several challenges as they strive to sustain food production with far-reaching consequences that extend beyond the agricultural frontiers. Consequently, the sustainability of the environmental resources surrounding the smallholder communities tends to be threatened as the smallholder sector production dwindles and household survival becomes more and 
more uncertain. Debate on how and why smallholders behave the way they do and the linkages between their decisions and the rest of the environment abound. This paper, therefore, seeks to document and highlight the specific challenges and conflicts the smallholder farmers face that have a direct bearing on environmental sustainability. We focus on a small rural community of Malingunde Extension Planning Area (EPA) located to the southwest of the capital district, Lilongwe, in central Malawi (Figure 1). Endowed with a wide array of natural resources that include a forest reserve and an important watershed, the proximity of Malingunde to the urban city of Lilongwe amplifies the environmental problems emanating from the interactive activities of the smallholder farmers in the area and those of the urban dwellers. As such, apart from typifying the smallholder farming and environmental land use management conundrum, the chosen study area represents a worst case possible scenario of environmental land cover management in Malawi. We will use the terms "smallholder farmer", "farmer", "farm household" and "household" interchangeably, unless otherwise stated.

\section{Background}

Since independence, in 1964, agriculture has continued to play a central role in defining Malawian rural livelihoods. Tobacco is the major export earner and contributes approximately $65 \%$ of the country's export earnings, followed by tea at $8 \%$ and sugar at $6 \%$. Maize is the major food crop, cultivated on over $60 \%$ of the arable land [5].

\subsection{Study Area}

Malingunde EPA is in traditional authorities (TAs), Masula and Masumbankhunda (Figure 1), where the Chewa people are the dominant ethnic group and trace their ancestral roots to the first Bantu-speaking "Maravi", who migrated into Malawi some 2,000 years ago [6]. Chichewa is the common language in the area and both matrilineal and patrilineal cultural marriage systems are in existence.

Figure 2. Biophysical characteristics and land use of Malingunde EPA.
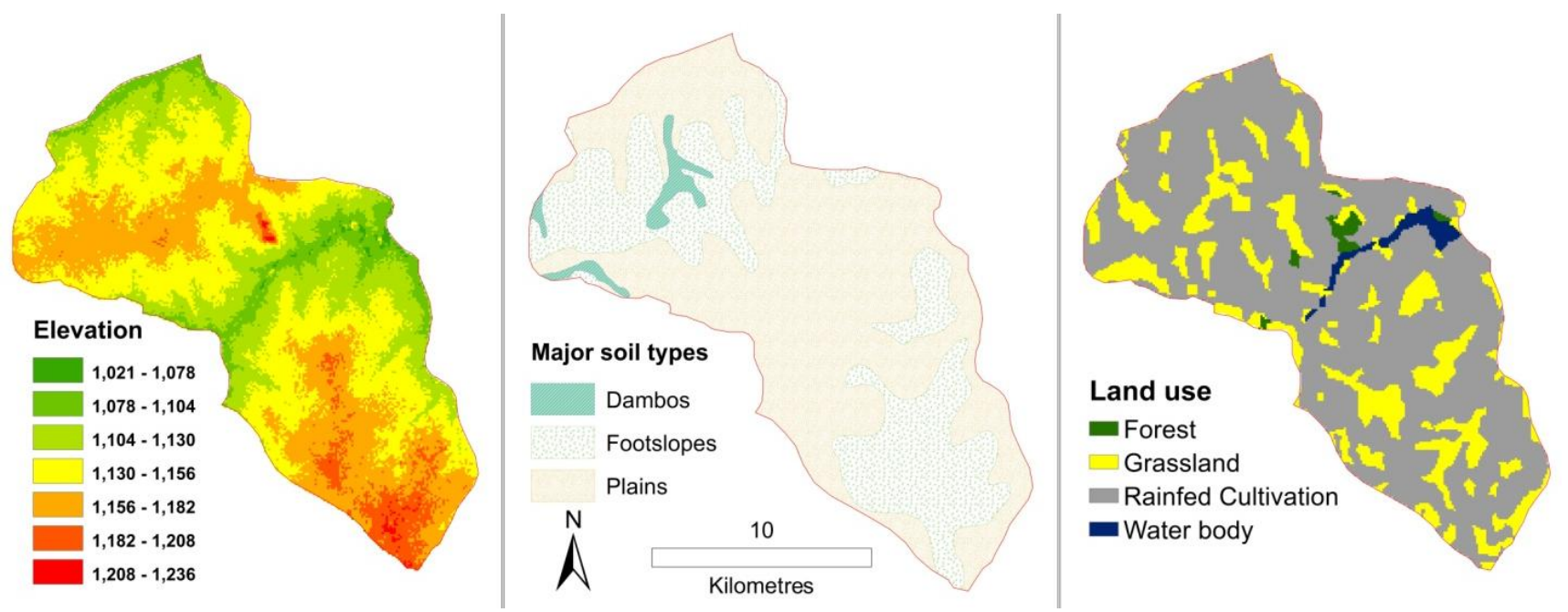

It forms a substantial part of the catchment area for the Kamuzu II Dam on the Lilongwe River, which supplies Lilongwe city with potable water. Sitting in the flat-lying Lilongwe Plains covered in dark red sandy clay or clay ferruginous soils, Malingunde has a warm tropical climate with mean 
annual temperatures of about 20-22.5 degrees Celsius, though they can drop to between 7.5 and 12.5 degrees Celsius in the winter months of June and July. There are three distinct seasons, cool, dry and rainy, in the district, with mean annual rainfalls of between 800 and 1,000 mm. The length of growing period (LGP) is between 135 and 150 days and usually coincides with the rainy season months of November to mid-April [7]. Much of the land is under rainfed cultivation through private leasehold or customary land tenures, dimba cultivation, grassland, plantation forests or natural forests and woodlands (Figure 2). Dimbas are small plots under low-level irrigation used to grow largely vegetables and, sometimes, sweet potatoes and maize.

\subsection{Administrative Structure}

Malingunde is one of the 193 EPAs under the Ministry of Agriculture. An EPA is an agricultural administrative unit that implements central government agricultural policies through provision of good farming methods for farmers on a one-on-one visitation basis (extension services). An extension service is the transfer of knowledge from researchers to farmers carried out by extension workers (EWs). EWs are therefore mandated to advise farmers on their decision-making and stimulate desirable agricultural developments by providing informal education for farmers through meetings, demonstrations and field days. As such, EWs require necessary orientation and facilities in technical knowledge, farming skills, economic analysis, research procedures and communication abilities. Malingunde EPA is under the Lilongwe Agriculture Development Division (ADD) of the Ministry of Agriculture through which all the agricultural technical details are communicated. However, its administrative responsibilities fall under the Lilongwe district assembly, through the local government ministry (Figure 3).

Figure 3. District/town assembly organizational structure.

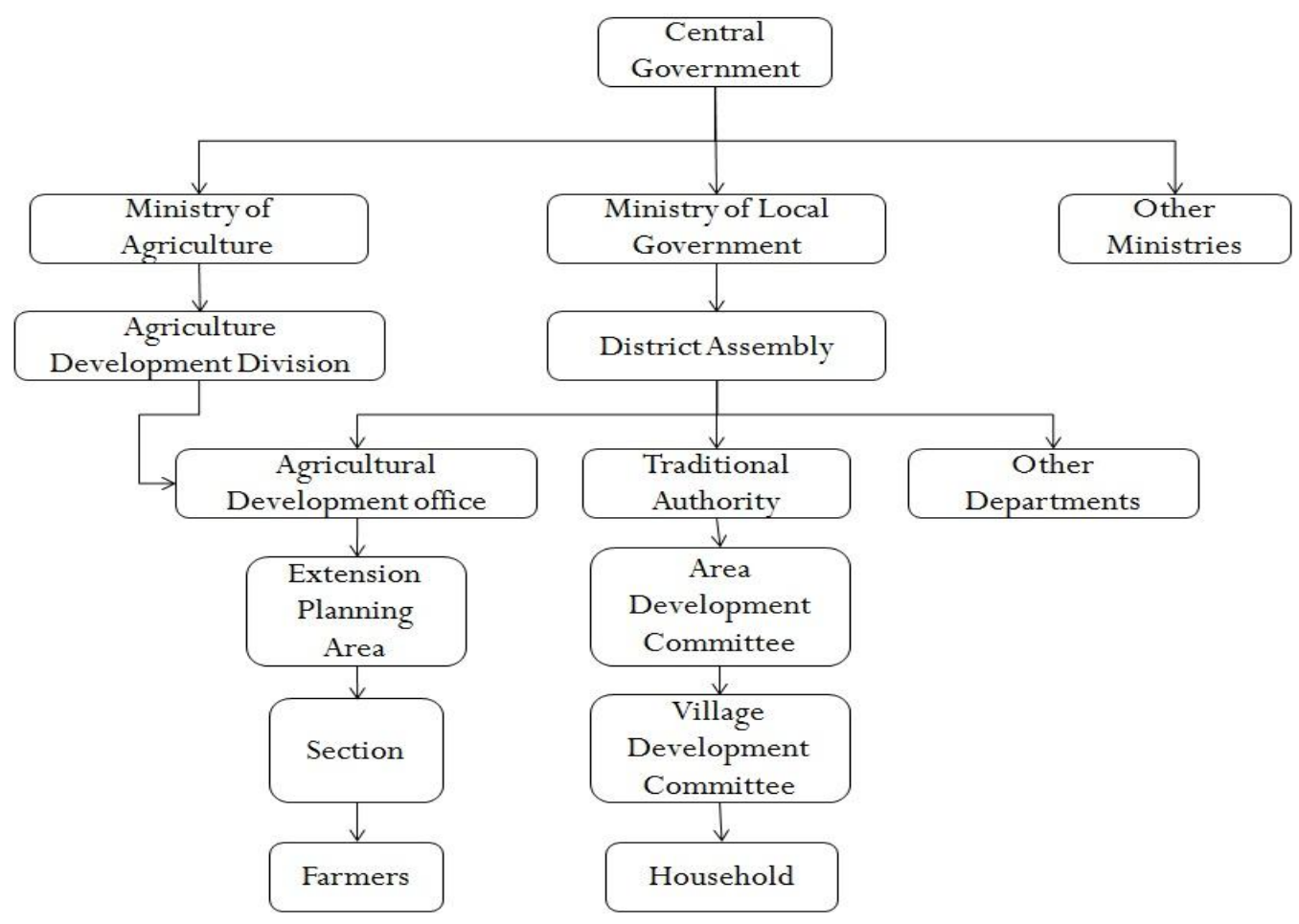


The average land holding size in 2006 is as shown in Table 1, together with those of two neighboring EPAs, Thawale and Ming'ong'o. The majority of the total arable land is under the smallholder farming system, and there is almost no mechanization.

Table 1. Average land holding size for Malingunde, Thawale and Ming'ong'o EPAs.

\begin{tabular}{ccccccc}
\hline EPA & $\begin{array}{c}\text { Total Farm } \\
\text { Families }\end{array}$ & $\begin{array}{c}\text { Total Smallholder } \\
\text { Arable Land (ha) }\end{array}$ & $\begin{array}{c}\text { Average Land } \\
\text { Holding Size (ha) }\end{array}$ & Sections & $\begin{array}{c}\text { Extension } \\
\text { Workers** }^{*}\end{array}$ & $\begin{array}{c}\text { Extension } \\
\text { Services Ratio*** }\end{array}$ \\
\hline Malingunde & 18,282 & 19,667 & 1.08 & 12 & $9(24)$ & $1: 2031(1: 761)$ \\
Thawale & 18,665 & 25,000 & 1.34 & 8 & $5(16)$ & $1: 3733(1: 1167)$ \\
Ming'ong'o & 22,667 & 30,766 & 1.36 & 15 & $12(30)$ & $1: 1889(1: 756)$ \\
\hline
\end{tabular}

*Number of extension workers as of 2011 (recommended); **Extension worker-to-farm family ratio as of 2011 (recommended) (adapted from: [7]).

\section{Smallholder Farming in Malawi}

Smallholder agriculture remains an important source of livelihood for a majority of the rural population. Approximately $84 \%$ of all value-added agriculture in Malawi comes from 1.8 to 2 million smallholder farmers [8]. The majority of smallholder farmers in Malawi still cultivate using hoe technology and rely heavily on family labor. It is estimated that only about $15 \%$ of the maize that is produced in the country is marketed, while the rest is used to meet subsistence needs [1]. This is not very surprising, considering that smallholder farming is focused mainly on growing enough food to sustain one's family subsistence needs in combination with some cash crops.

\subsection{Household Characteristics}

In a household field survey conducted in the study area in April 2011 and January 2012, 3,533 smallholder farmers were interviewed by the authors. The farmers were selected from 12 sections of Malingunde EPA, with each section contributing at least 290 random farmers. The following socio-economic data were collected: household size; total land under cultivation; total land under maize (corn) cultivation; land under other crops; annual total maize yield (food); access to production materials (hybrid seed and organic fertilizers); estimated annual income; access to good farming methods; income-generating activities (IGAs) that the farmers engage in apart from cultivating their land; labor and land availability; soil condition; and educational level of the head of household.

Most of the households, on average, have four or more members (Table 2), and illiteracy levels are very high, with almost two-thirds of the respondents unable to read and/or write. All farmers depend on family labor to produce crops on the pieces of land, which most of them claimed was sufficient for their production, provided all production materials were available. Almost all farmers grow maize as a staple food in conjunction with varying combinations of cash crops that include groundnuts, sweet potatoes, soybeans, tobacco and cassava.

The mean household size of the data collected is 4.4 persons (Table 2), requiring $792 \mathrm{~kg}$ of maize to feed itself per year. The land that the farmers allocated to food production averaged 0.59 ha. According to production estimates of the 2010 growing season, this hectarage can produce at best $2,700 \mathrm{~kg}$ of maize, provided production materials are available, and at worst only $500 \mathrm{~kg}$. With most farmers 
lacking crop production materials, it is not surprising that most of the farmers failed and continue to fail to produce enough food to sustain their households. The average total land per farmer ( $0.97 \mathrm{ha})$ is higher than the average allocated to food production $(0.59 \mathrm{ha})$. One would therefore expect an adjustment in the crop distribution to allocate more land to food production. However, the field survey revealed that the crop combinations rarely change at the end of the cropping year. As such, despite having room to expand the land allocated to food production to compensate for the low production due to the lack of production materials, the farmers continue to operate at a disadvantage year in, year out. The poor crop markets do not help to rescue the farmers either, as the cash crops cannot fetch enough to cover the food and cash deficits.

Table 2. Descriptive summary statistics of field survey data collected (land is in hectares).

\begin{tabular}{ccccc}
\hline Household Characteristic & Minimum & Maximum & Mean & Standard Deviation \\
\hline Household size (including children) & 1 & 12 & 4.39 & 1.72 \\
Children less than 15 years & 0 & 9 & 2.12 & 1.36 \\
Children older than 15 & 0 & 8 & 0.49 & 0.89 \\
Total arable land & 0.20 & 7.69 & 0.97 & 0.55 \\
Land allocated to maize & 0.00 & 4.45 & 0.59 & 0.32 \\
Land allocated to groundnuts & 0.00 & 2.43 & 0.32 & 0.25 \\
Land allocated to tobacco & 0.00 & 1.21 & 0.015 & 0.08 \\
Land allocated to soybeans & 0.00 & 0.81 & 0.022 & 0.07 \\
Land allocated to cassava & 0.00 & 0.40 & 0.002 & 0.02 \\
Land allocated to sweet potatoes & 0.00 & 0.81 & 0.020 & 0.072 \\
Land allocated to other crops & 0.00 & 0.40 & 0.003 & 0.024 \\
\hline
\end{tabular}

\subsection{Smallholder Farming Challenges}

Operating under a low-input rainfed system, the country's economic performance thus depends largely on how its smallholder farmers perform [5]. Malawi's agricultural productivity, particularly among the majority of the smallholder farmers, has, however, fallen a long way below its potential, given the available technology. For example, local maize and Burley tobacco yields have rarely reached 1.5 tons per hectare [5]. This is substantiated further by the $74 \%$ of the respondents, who could not produce enough food in the field survey.

As of 2002, the per capita maize production was on average $49 \mathrm{~kg}$ for the ultra-poor, $63 \mathrm{~kg}$ for the poor and $116 \mathrm{~kg}$ for the non-poor, all falling short of the average $155 \mathrm{~kg}$ minimum staple food requirement and leaving even the non-poor in a deficit position [9,10]. Mvula [11] and his colleagues identified similar categories in 2003. The "well-to-do" have food stocks that on average last eight to nine months of the year; the "fairly well-to-do" have food sufficient to cover four to six months; and, finally, the "have-nots" usually have only one to two months of their household's food supply needs $[6,11]$. While everyone's food security has deteriorated, the latter group has experienced the most precipitous slide downwards [6]. A detailed survey by Peters [12] found that the poorest farmers were reducing the proportion of their maize harvest that they sold to conserve household food stocks. However, their extremely low level of food output necessitated the purchase of maize in rural markets, 
where the role of the government-owned Agricultural Development and Marketing Corporation (ADMARC) as a price stabilizer is/was declining, making them more vulnerable.

Malawi's agricultural productivity is, therefore, under threat. The 2008 population census estimated the country's population at 13.1 million and growing at $2.8 \%$ per annum, possibly doubling by 2025 [13]. This puts enormous pressure on agriculture to grow at levels sufficient to feed the growing population. Many of the proposed solutions are aimed at improving the smallholder sector, with varying degrees of agreement on their impacts. In this section, we discuss in detail the dynamics of the factors that would enhance agricultural production in the name of availability of sufficient labor, land and agricultural production materials and how they together intertwine to exacerbate the food security problem, hence threatening the environment, for smallholder farmers in rural Malawi.

\subsubsection{Labor}

Farmers' reliance on casual labor has grown so much, resulting largely from the fact that their livelihood strategies revolve around the need to obtain food on a day-to-day basis. Labor is, therefore, a key asset for smallholder farmers in rural Malawi. The quality and quantity of labor available to the farmer in terms of numbers, educational level, skills and health constitute the human capital. This, then, becomes the basis for constructing household livelihood strategies [14] that are essential in enhancing the agricultural productivity. Ganyu is a short-duration casual labor contract for unskilled work paid in cash or kind $[14,15]$.

As the population grew, the labor supply began to outstrip demand, reducing the bargaining power of ganyu workers with respect to wage levels and the nature of the work tasks demanded. The growing prevalence of HIV/AIDS, compounded by occasional famine, reinforced this tendency by limiting the number of people who were able to employ ganyu labor [6]. The removal of the fertilizer subsidy in the early 1990s, when the Malawi government ceded to World Bank pressure, caused smallholder farmers to drastically reduce their improved input usage. This caused maize productivity to decline and shifted smallholder allocation of labor from their family farms to larger farms producing at scale or to non-agricultural activities [6]. As a consequence of the suboptimal labor inputs, productivity on smallholdings further decreased [16].

Ganyu labor remains important in rural Malawi for two main reasons: (i) it provides supplementary labor for labor-deficient farmers, due to HIV/AIDs-related issues that have led to high numbers of female/children-headed households; and (ii) it provides a ready sustainable way of obtaining food when households' food supplies run out. It interrelates with the high risks in agricultural production and the problem of food deficiency and provides a means for risk sharing for the employers and food security for the laborers [14]. For the majority of the rural farmers, therefore, ganyu labor has become a way of life, but one that exacerbates rather than solves the farmers' food production constraints [6].

This is the case, because both the opportunities and necessity for ganyu increase during the rainy season. The opportunities arise from the increased agricultural activities as the cropping season begins. It becomes a necessity, because this is the time when most households are worst hit by hunger after depleting their food reserves. The overall effect during this season, then, becomes a labor allocation dilemma for ganyu laborers. Trying to satisfy their immediate need for food, they are forced by circumstances to do ganyu labor at the critical time when they should be preparing, planting and 
weeding their own fields [6]. In doing so, they unwillingly exacerbate their future food deficiency. Being a rainfed agricultural production system, planting late has serious consequences on output. However, poor farmers do not have much of a choice but to plant late, because they must first do ganyu to earn enough cash to buy production materials.

Women are just as equally involved in ganyu as men, despite there being large gender differentials in remuneration. Men reportedly tend to earn twice as much as women of the daily piecework rates [17]. These differentials are locally justified in that: (i) men put in a full day's work, whereas women are distracted by domestic duties; (ii) besides attitudinal differences regarding the value of female labor, there is the very real issue of need for cash for women. Also, with their lack of other income sources, women's opportunity costs of their labor are significantly lowered; and (iii) women are restricted to ganyu work close to their homes, whereas men venture longer distances, thereby increasing their chances of finding higher wage levels $[6,18]$.

Traditionally, women and children work as unpaid family labor in smallholder agricultural production. Much in the way that their husbands expect them to work unpaid on the family farm, now women (and men alike) expect their children to do ganyu labor to contribute to household income [6]. This expectation is not strange, as traditionally, children have always helped with the household workload doing domestic labor and cultivating the family agricultural fields, as well as doing household-based crafts, like weaving and rope-making, without expecting any remuneration. As such, parents see their offspring as economic dependents who should be helping them to earn ganyu income, rather than doing ganyu on their own account. However, as Bryceson [6] notes, teenage estrangement is thwarting this traditional ideal of a collective rural smallholder household labor effort, with modern youth increasingly unwilling to do so. She attributes this trend of events to the introduction of free primary education in the mid-1990s. Though it was an extremely positive development, free primary education tends to serve as a communication barrier between the younger children generation and the parent generation. This is largely because with free primary education, the rural youth are already better educated than their parents. On top of that, there is the issue of human rights that came with the introduction of multi-party democracy in 1992. At the village level, many older people equate human rights with the perceived individualistic behavior of the youth at the expense of the age-old moral values of the collective community [6].

Considering that children make up to $60 \%$ of total population (Figure 4(a)), this teenage estrangement ties up a significant portion of the family labor force. With female-headed households owning on average even lesser land per household (and per household size) than their male-headed counterparts, these highlighted factors worsens the problems of the female farmers more than the male-headed households. Not only are the female-headed households producing little per hectare due to low fertilizer use (lack of cash to buy) and less land, but also they have limited options in terms of both ganyu and the variety of more rewarding crops they can produce with their limited labor. This is a predicament $36 \%$ of the households in Malingunde find themselves in (Figure 4(b)), for which only $3 \%$ of total land owned by the female-headed households is allocated to growing tobacco as a cash crop compared to $10 \%$ for the male-headed ones. 
Figure 4. Population structure for Malingunde EPA.

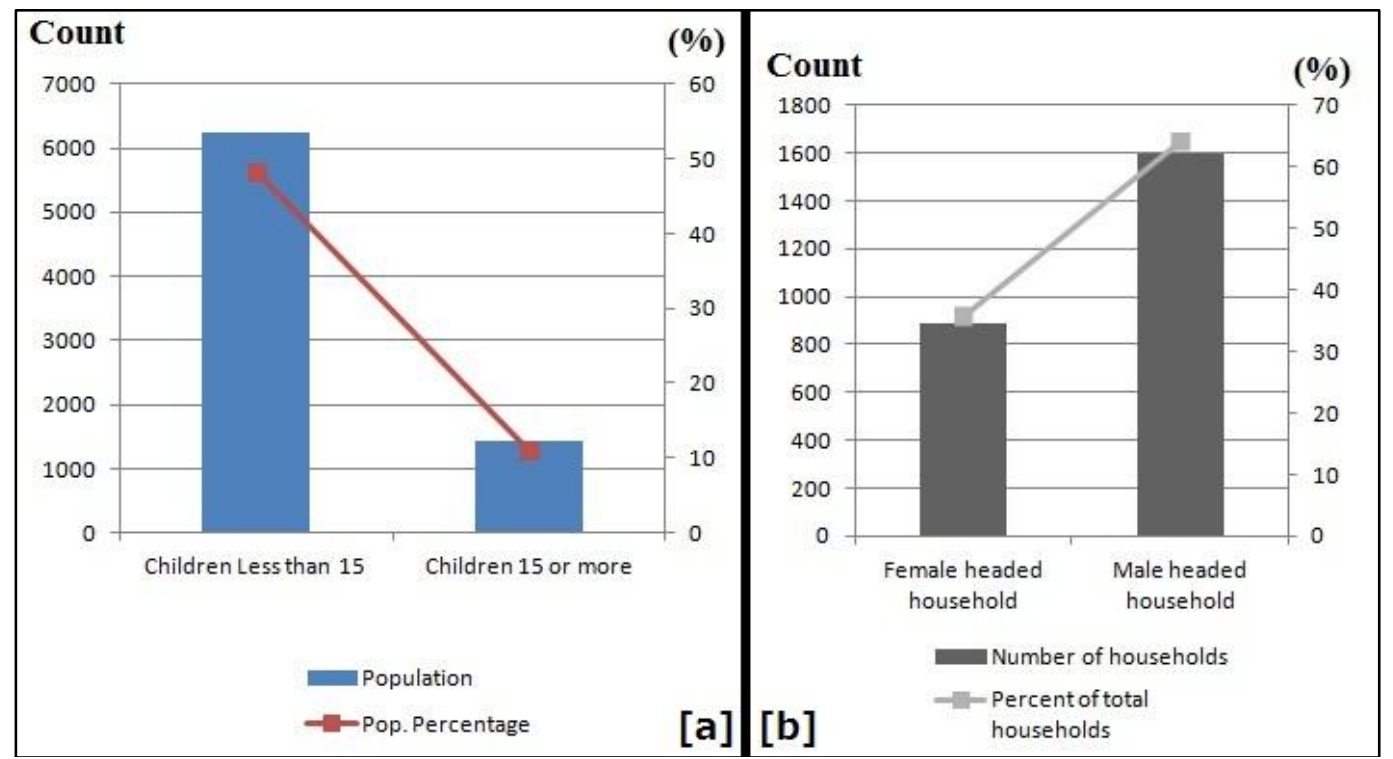

\subsubsection{Land}

The importance of family labor in farm work and the lack of mechanization in agricultural production imply that the state of the soil condition to support agricultural production becomes very critical. However, soil conditions have deteriorated in the past couple of decades, due to inappropriate land management practices and agriculture on unsuitable land and widespread use of fertile soils for brick production and construction [19]. Coupled with insufficient production materials, the soils have since been depleted of essential nutrients as a result. A study conducted in 1998 indicated that Malawi's soils lose on average 40.0, 6.6 and $32.2 \mathrm{~kg}$ per hectare per year of nitrogen $(\mathrm{N})$, phosphorus (P) and potassium (K), respectively [5].

Land remains the most significant productive asset for the majority of Malawians, yet it is far from being equitably distributed [20]. Alwang and Siegel [21] estimate that $70 \%$ of Malawian smallholder farmers cultivate less than 1.0 hectare, with the median area cultivated being 0.6 ha, and devote $70 \%$ of the land to maize production, the main staple food. As shown in Figure 5, land distribution in Malingunde follows similar trends. However, though the mean total land per household increases as the household size increases, the per capita total land is decreasing steadily. This is largely attributed to poor land administration by the TAs, who have an informal and ambiguous authority to distribute the vast customary land to their constituents, and poor family planning choices on the part of the farmers. Again, the average total arable land per household has also reduced by at least 0.1 ha between 2006 and 2012 (see Tables 1 and 2).

In terms of gender, the land distribution puts women farmers in an even worse situation. In Figure 6, male-headed households edge the female-headed households out both in terms of total land owned and total land per capita. In both cases, though (Figures 5 and 6), the impact of poor family planning and HIV/AIDS that force relatives to "adopt" the orphaned children is evident in the low per capita of cultivable land as household size increases. 
Figure 5. Mean total land and total land per capita distribution per household size in Malingunde EPA.

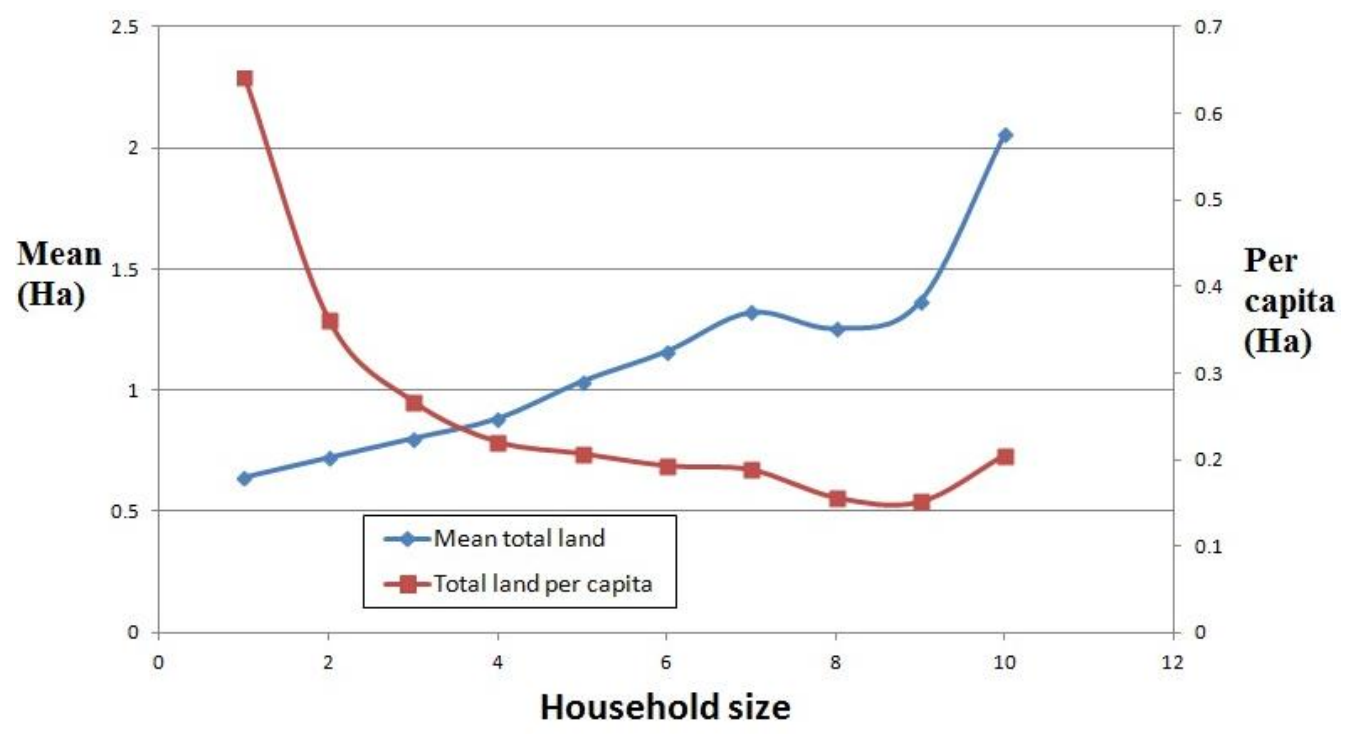

Figure 6. Mean total land and total land per capita distribution per household size by gender of head of household in Malingunde EPA. Note: $\mathrm{M}=$ Male; $\mathrm{F}=$ Female.

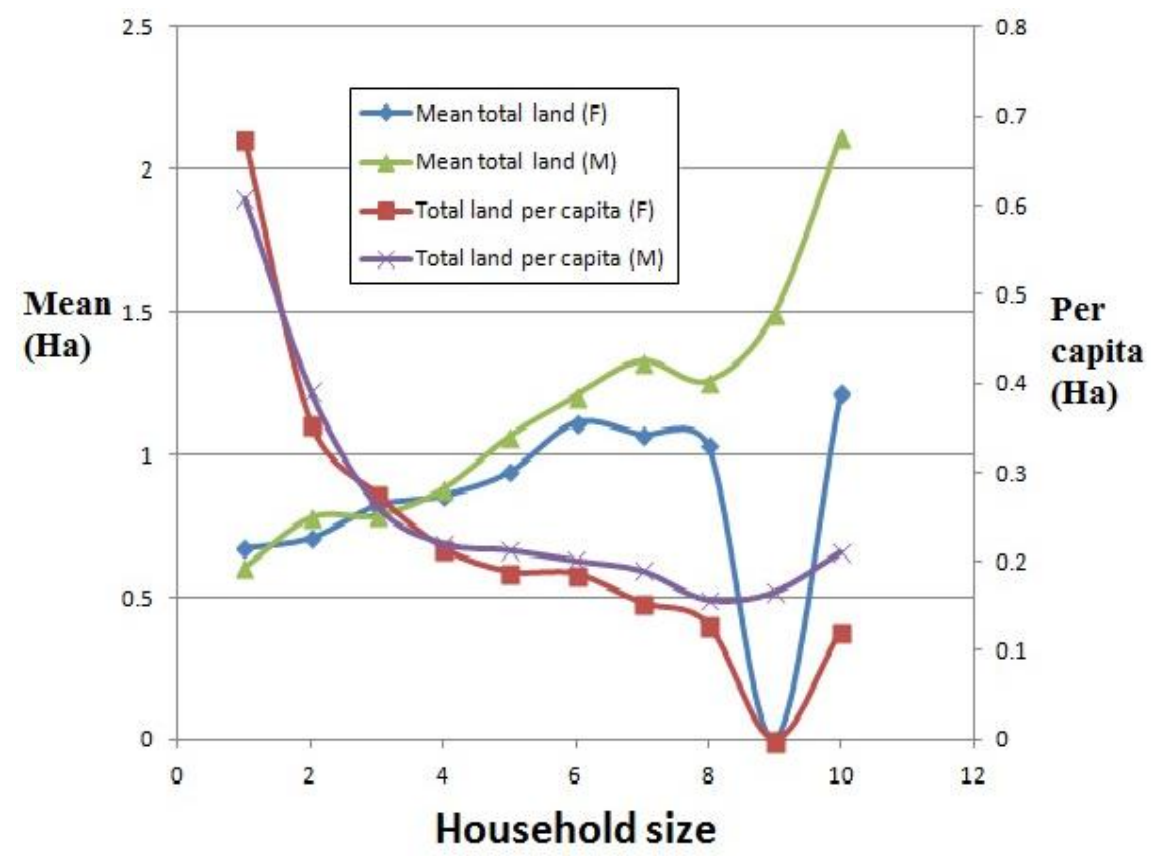

\subsubsection{Other Factors}

While all the problems in the preceding discussion exist and define the deeper underlying causes, most farmers surveyed expressed satisfaction with the amount of land, the family labor they have and the condition of their soils for agricultural purposes on the condition that they have all the production materials and skills. 74\% of those interviewed could not produce enough food for their households during the past couple of years, due to lack of access to production materials (cash unavailability), subsidized production materials from the central government and good farming methods (extension 
services). The former two directly relate to households' over-dependence on the declining economic returns from ganyu, as per the highlighted issues in Section 3.2.1. The latter relates to inadequate capacity by the agricultural ministry to educate the smallholder farmers on new farming techniques. This is especially in the form of under-staffing of the EPAs. For instance, Malingunde EPA has 12 sections, with each section supposed to have at least two extension workers. However, for the past seven years, each of these 12 sections only had one EW, putting the ratio of extension worker-to-farm household at 1:1,488, instead of the recommendation of at most 1:500 [7]. Secondly, these EPAs are also heavily under-funded, limiting further their potential to reach out to more farmers. Though not significant, these EWs also often lack the necessary orientation and facilities in technical knowledge, farming skills, economic analysis, research procedures and communication abilities [22].

To circumvent these understaffing problems of EWs, the district assembly employs the village technician and model village approaches. Village technicians are selected outstanding farmers who are taught new technologies by the EWs, so that they can pass on the technologies to fellow farmers for easy adoption. Under the model village concept, an EW identifies the problems affecting a village and resources locally available. He then develops an action plan together with the farmers in that locality in a participatory manner [7]. All the agricultural activities are then concentrated in that village for about three to five years. After five years, the villagers are expected to be independent to work without relying much on the EW. In 2006, Malingunde EPA had eight model villages, and the number reduced to five in 2012 out of the total 837 villages in the EPA. It also boasts of 120 village technicians against 18,282 smallholder households. Despite all these efforts in the past couple of decades, smallholder sector production continues to drop, leaving households vulnerable.

The other important factor concerns the performance of agricultural markets. Groundnuts, cassava, sweet potatoes, tobacco and soybeans are primarily grown as cash crops in the study area. However, except for tobacco, which has a well-structured market system, the market framework for the rest of the crops is discouragingly exploitative. Private vendors representing both corporate and private businesses dominate the rural agricultural markets located at Malingunde, Sinyala and Phirilanjuzi in the study area (Figure 1). Despite offering better prices than the government-owned ADMARC markets (at Sinyala, Dickson and Phirilanjuzi), the vendors' prices are nevertheless low for any meaningful sustenance of the production. Without much of a choice, the farmers still opt to sell some of their produce at these markets rather than waste it away. The case of tobacco is largely the other way round to the rest of the cash crops. That is, while the market structure for tobacco is well organized and seemingly less exploitative than that of the rest of the cash crops, the input costs to grow tobacco are very much higher than those of the rest of the crops. These factors, in the end, discourage most farmers from growing cash crops, as Table 2 shows, in that, on average, less than $30 \%$ of the total arable land is allocated to cash crops. In any case, commercial maize production has become increasingly unremunerative for smallholder farmers, other than those producing on a large scale with adequate capital to buy fertilizers [23].

Consequently, enhancing agricultural productivity is almost impossible for most farmers, where vast numbers of them live in exceptionally high-risk environments in which basic survival is a day-to-day uncertainty. Minus all the factors discussed in this section, the yield stagnation and fluctuations can, to some degree, also be attributed to natural phenomena, like unreliable rainfall and droughts. For those that failed to produce enough food for one reason or the other in the field survey, 
$64 \%$ of them engaged in off-farm activities to supplement food requirements for their households. It is at this point that authorities begin to worry about the environment.

\section{Environmental Land Use Management}

The 2001 Lilongwe District State of Environment Report identifies riverbank cultivation, soil erosion, loss of biodiversity, deforestation and climate change as some of the environmental problems. Those specific to Malingunde include land degradation around the Kamuzu II Dam and deforestation of the neighboring Dzalanyama forest reserve (Figure 1). As of 2006, only two TAs, Mazengera and Kalolo, out of the 18 TAs in the Lilongwe district, had received funding from the environmental and natural resources management project of the district assembly. These were in the form of afforestation, agroforestry and water conservation micro-projects [7]. The donor-funded Malawi Social Action Fund Third Phase III (MASAF III) has also facilitated similar environmental projects or projects having an environmental component. The mitigating interventions to environmental degradation in Lilongwe district and Malingunde, in particular, are, therefore, sparse, both temporally and spatially, and fall a long way short in alleviating the problems.

Meanwhile, the smallholder agriculture sector is struggling to sustain itself, and in the process, farmers are being forced to seek off-farm IGAs to supplement their requirements. However, most of the IGAs that are environmentally sustainable require substantial capital injections. This makes them out of reach for most of the rural farmers, forcing them to resort to engaging in environmentally unsustainable activities. In the study area, these activities include brick burning, firewood collection and charcoal production. We then discuss the implications of the charcoal production in detail as a representative IGA that has the highest impact on environmental degradation among the three and its implications on smallholder agriculture sector production.

\section{Charcoal Production}

\section{The Charcoal Value Chain}

The charcoal industry provides significant employment throughout its value chain. Out of the approximately 100,000 people that depend on charcoal for their livelihoods, slightly over half are involved in the actual production. $62 \%$ of the producers are in the small- (less than 30 standard bags per month) to medium-scale (between 30 and 100 standard bags per month) production ranges, together producing approximately $67 \%$ of the annual charcoal tonnage [24]. A standard bag of charcoal weighs between 35 and 50 kilograms. The small-scale producers' category is comprised of those venturing into charcoal production as a coping mechanism against food shortage and/or cash needs, while the medium-scale ones are slightly business-oriented, but are not well cash-endowed [24]. It follows, therefore, that there is a big overlap between the smallholder farmers, who struggle to feed themselves and are in food deficit year-in, year-out, and the small- and medium-scale charcoal producers.

While the agricultural production challenges push the smallholder farmer household into tighter corners to survive, the nearby urban city of Lilongwe provides an opportunity in the study area. Less than $30 \%$ of the urban population is connected to the national electricity grid [24]. It is estimated that $90 \%$ of the urban families in Malawi rely on biomass energy, with charcoal being the dominant energy 
source for the main urban centers of Blantyre, Lilongwe, Zomba and Mzuzu [25]. The high electricity tariffs mean that most of those connected to the national electricity grid reduce its usage to lighting only, using charcoal for cooking and heating. As a result, urban consumption is the primary market for the highly traded charcoal. Located in close proximity to Lilongwe city and directly linked by a relatively accessible unpaved road, charcoal from the Dzalanyama forest reserve has a ready and steady market (Figure 1).

\section{Charcoal-Making Process}

Charcoal is produced by heating fuelwood (or any other raw biomass) in some type of kiln with limited access to air in a process called carbonization [26]. Carbonization creates a fuel of higher quality than the original fuelwood. Besides charcoal, fuelwood is the main energy carrier for cooking and heating in the developing world. According to Emrich [27], charcoal production can be categorized into traditional and modern. The traditional approach is characterized by:

- zero or low investment;

- use of construction materials, which are at hand on the site or available nearby, e.g., clay, soft-burnt bricks;

- $\quad$ zero or low maintenance costs achieved by avoiding metal parts in the kiln construction as much as possible;

- manpower not being a major concern; normal raw materials consisting largely of wood logs (other types of biomass may be carbonized also);

- by-product recovery being limited, owing to the fact that no sophisticated equipment is employed; and

- typically being a family or cooperative initiative.

A marked difference between traditional and modern charcoal production is the employment of sophisticated technologies and/or high capital investments, in which case returns from the process include some other essential by-products of the carbonization process. Because of the inherent inefficiencies in the traditional approach, there is substantial loss of carbon and energy from the starting fuelwood (primarily as carbon dioxide) and a more significant production of products of incomplete combustion [26] than in the modern approach. Much of the charcoal produced today has been made by families or small businesses using the traditional approach. Though inefficient, as it employs simple technology and low capital investment, the traditional approach is nevertheless precise and skilful [27].

Common in Malawi among the traditional approaches of charcoal production are the pit and earth mound kiln methods. To cut on raw material transportation costs, small- to medium-scale charcoal makers produce their charcoal at the place where they collect the raw materials. Because this will involve frequent movements as the raw materials on site get depleted, employment of heavy equipment is reduced to the bare minimum, if not none at all [27]. The business of charcoal making requires skill, patience and the readiness to observe correct working methods at all times and in all weathers. These "technical secrets" are usually handed down from father to son and kept under wraps and well-guarded by the family [27]. An important part of the charcoal-making experience concerns the insulation of the 
charcoal pit or earth mound to control airflow. If not well controlled, excess oxygen will cause the charcoal to burn away to ashes and destroy the result of several days' work, not to mention wasting the fuelwood. Depending on the amount of wood and the size of the kiln, the charcoal-making process can take more than a month, although the smallest kilns will produce charcoal in a few days [24]. The insulation material readily and cheaply available is earth, and this is one of the factors that greatly contribute to the inefficiencies of the traditional approach.

\section{Competition for Labor}

Charcoal production requires close monitoring, as such producers have to spend days off their farms tending to their char. Again, its demand and production peak during the rainy season [24]. This, ironically, is a critical time when the rainfed smallholder agriculture sector requires close attention. It is, again, during this season that households are worst hit by food scarcity after depleting their food reserves. As discussed in Section 3.2, this competition for labor between the farmers' own farm plots and the need to survive the season, by producing charcoal, spirals the household food security deeper into deficit. As the smallholder farming households in the study area continue to be in perennial food deficit, any nearby forest resource seems to offer an easier way out of perpetual poverty. Being readily accessible from/to the urban center of Lilongwe city, the plight of forest reserve resources in Malingunde is dealt a further blow to sustain the biomass energy demands of the rapidly increasing population of the capital. It is not surprising, then, that Dzalanyama forest reserve is one of the most threatened natural ecological systems in Malawi, due to deforestation caused largely by charcoal production.

\section{Controlling Charcoal Production}

Despite the industry itself being big in Malawi, charcoal production is generally illegal, and the efforts to stop it are usually half-hearted. Due to limited government resources, much of the effort to stop charcoal production is concentrated on stopping the transportation of the produced charcoal from production sites to the urban markets, rather than stopping the production itself. Well-established corruption syndicates by those operating the checkpoints on the transportation routes equally hamper this approach, apart from the traders' cunningness to use uncharted routes to avoid the checkpoints. Government officials operating the checkpoints include people on duty on roadblocks and traffic police officers. These officials, instead of confiscating the charcoal altogether, often demand payments in cash or kind before they can allow the traders to pass with the charcoal. This informal private "taxation" is largely out of sympathy of the officials for the traders knowing fully well that confiscating the charcoal would mean denying the trader and his/her family a means of survival. This is not to mention the fact that the corrupt officials take full advantage of the lack of political will on the part of the government to enforce the law to ban charcoal production. Banning charcoal production will mean denying many households their livelihood, and in turn, the households will deny the politicians votes during elections; and government is unwilling to sacrifice potential votes at the expense of environmental policy enforcement or change. 


\section{Concluding Remarks}

The main objective of this article was to develop a deeper understanding of the interdependences between smallholder farming and the state of environmental management in rural Malawi. We have examined the agricultural local governance framework in Malingunde EPA, its contribution to food security and how it conflicts with overall land and forest resources management. We have also examined the charcoal production process and discussed its implications on agricultural production and environmental sustainability. Much as population growth and poverty play important roles, the complex forces of changing economic opportunities have the most significant impacts in the study area. In general, the direct interviews, field surveys and document analyses have shown that the smallholder households employ inappropriate land management practices, engage in agricultural production on unsuitable land and use fertile soils, timber and firewood for brick production and construction and, secondly, engage in charcoal production (deforestation) as a coping mechanism against food deficiency. Apart from the smallholder households' inability to meet their food and/or cash requirements from agriculture, their main activity, the resulting forest cover loss in the latter, is also due to the high urban biomass energy demands, of which $93 \%$ comes from fuel wood and charcoal and the study area's proximity to the same.

Average arable land per farmer declined by approximately 0.1 ha between 2006 and 2012. The per capita land remains critically low, despite general increasing trends in land holdings as the household size increases. Income levels are further affected by households' access to sufficient labor, especially in this context, where, in addition to working on one's own household farm, labor may also be deployed in off-farm economic activities to generate additional income. The story is worse for female-headed households compared to their male-headed counterparts.

The majority of the crop produce ends up being used to subsist, with very little sold to the usually exploitative rural markets. This trend serves to push more farmers into food deficiency, and while charcoal production remains illegal and brick burning using fertile soils highly counter-productive, these activities have tended to provide an alternative source of livelihood in Malingunde. However, while detrimental in its own right, this environmental degradation in the area cannot be explicitly pinned to, for instance, total charcoal supply being out of balance with wood stocks or insufficient land. It is rather usually due to failures to provide incentives to manage land and forest resources in a manner that allows regeneration of both the soils and wood stocks in the area.

We note that the provision of incentives to manage land and forest resources in the study area are largely hampered by limited financial resources. So, apart from encouraging efforts to civically educate the households on the evils of environmental degradation, ways in which to generate public financial resources for local environmental management should also be explored. A lot of public financial resources are lost through uncollected revenue, while the state of the environment continues to plummet from the twin activities of brick burning and charcoal production. Munthali [28] and Kambewa [24] and colleagues argue that a shift in policy to formally legalize and tax, for instance, the charcoal production would generate huge financial resources. While Kambewa [24] and colleagues look at how much government is losing in terms of revenue in his advocacy, Munthali [28] looks at how much the environment is losing when he argues that the financial resources realized would go a long way in providing incentives to manage the land and forest resources in the study area. With the 
realized resources, proper planning of the low-cost agricultural smallholder sector would be implemented. An improvement in the quality and quantity of the smallholder agriculture sector production would promote significantly the environmental management efforts. Secondly, while land distribution is not equitable in the study area and the per capita cultivable land low, ownership of the customary land remains with the TAs. In the end, farmers do not have full legal status and, as such, cannot lease or use the land as security for mortgage loans for agricultural development purposes. With land held in common under customary land, no one is, therefore, responsible for the uneconomic and wasteful use of land and forest resources, because no one holds land as an individual.

Employing over $85 \%$ of the population in the study area, the highlighted inefficiencies in the smallholder farming system create a lot of pressure on natural resources. The ecological landscape of Malingunde and its natural resources are under massive degradation. The environmental risk factor, created by the activities of the smallholder households, is, as such, very large. In conclusion, while it is well established that smallholder agriculture determines the pace and direction of overall economic growth, it is less apparent to many a Malawian that it also defines the state of the environment. As such, once accorded the necessary attention to improve it, we will also improve management and sustainability of the environment in Malawi.

\section{Acknowledgements}

We thank Douglas Malasa, the Agriculture Extension Development Coordinator (AEDC) heading Malingunde EPA, and his staff for the positive response and support during the data collection process.

\section{Conflict of Interest}

The authors declare no conflict of interest.

\section{References}

1. Chirwa, E.W.; Matita, M. From Subsistence to Smallholder Commercial Farming in Malawi: A Case of NASFAM Commercialisation Initiative. Available online: http://opendocs.ids.ac.uk/ opendocs/handle/123456789/2268 (accessed on 7 September 2012).

2. Governement of Malawi and The World bank. Malawi Poverty and Vulnerability Assessment: Investing in Our Future; Ministry of Economic Planning and Development/The World Bank: Lilongwe, Malawi/Washington, DC, USA, 2007.

3. Environmental and Socio-Economic Baseline Study-Malawi; Norwegian Agency for Development Corporation (Norad): Oslo, Norway, 2009.

4. Kaimowitz, D.; Angelsen, A. Economic Models of Tropical Deforestation. A Review; Centre for International Forestry Research: Bogor, Indonesia, 1998.

5. Tchale, H. The Efficiency of Smallholder Agriculture in Malawi; World Bank: Lilongwe, Malawi, 2009.

6. Bryceson, D.F. Ganyu casual labour, famine and HIV/AIDS in rural Malawi: Causality and casualty. J. Mod. Afr. Stud. 2006, 44, 173-202. 
7. Government of Malawi. Lilongwe District Socio-Economic Profile; Lilongwe District Assembly: Lilongwe, Malawi, 2006.

8. Malawi Country Economic Memorandum: Policies for Accelerating Growth; World Bank: Washington, DC, USA, 2003.

9. Food and Agriculture Organization/World Food Program. Crop and Food Supply Assessment Mission to Malawi. Available online: http://documents.wfp.org/stellent/groups/public/documents/ ena/wfp036450.htm (accessed 10 August 2012).

10. Statistical Yearbook 2002; National Statistical Office, Government of Malawi: Zomba, Malawi, 2002.

11. Mvula, P.M.; Chirwa, E.W.; Kadzandira, J. Poverty and Social Impact Assessment in Malawi: Closure of ADMARC Markets; Wadonda Consult \& World Bank: Zomba, Malawi, 2003.

12. Peters, P. Rural income and poverty in a time of radical change in Malawi. J. Dev. Stud. 2006, 42, 322-345.

13. National Statistical Office. Republic of Malawi 2008 Population and Housing Census Preliminary Report; Government of Malawi: Zomba, Malawi, 2008.

14. Takane, T. Labour use in smallholder agriculture in Malawi: Six village case studies. Afr. Study Monogr. 2008, 29, 183-200.

15. Oversees Development Institute. Available online: http://www.odi.org.uk/ (accessed on 17 August 2012).

16. Edriss, A.; Tchale, H.; Wobst, P. The Impact of Labour Market Liberalization on Maize Productivity and Rural Poverty in Malawi; Robert Bosch Foundation, Policy Analysis for Sustainable Agricultural Development (PASAD) Project-University of Bonn: Bonn, Germany, 2004. Available online: http://www.pasad.uni-bonn.de/pasadJournalpaper.pdf (accessed on 14 August 2012).

17. Whiteside, M. When the Whole Is More Than the Sum of the Parts: the Effect of Cross-Border Interactions on Livelihood Security in Southern Malawi and Northern Mozambique; 1998. Available online: http://www.eldis.org/assets/Docs/27437.html\#.URjo4h1JPpU (accessed on 17 August 2012).

18. Chipande, G.H.R. Innovation adoption among female-headed households: The case of Malawi. Dev. Change 1987, 18, 315-327.

19. Country Environmental Profile for Malawi; AGRIFOR Consult: Les Isnes, Belgium, 2006.

20. Chinsinga, B. Exploring the Politics of Land Reforms in Malawi: A Case Study of the Community Based Rural Land Development Programme (CBRLDP); University of Manchester: Manchester, UK, 2008. Available online: http://www.ippg.org.uk/papers/dp20.pdf (accessed on 7 February 2013).

21. Alwang, J.; Siegel, P.B. Labour shortages on small landholdings in Malawi: Implications for policy reforms. World Dev. 1999, 27, 1461-1474.

22. Mobarak, A.M.; BenYishay, A.; Beaman, L.; Fatch, P.; Magruder, J. Using Social Networks to Improve Agricultural Extension Services; Yale University: New Haven, CT, USA, 2012. Available online: http://www.mcc.gov/documents/Mobarak_Malawi_MCC.pdf (accessed on 19 October 2012).

23. Levy, S.; Barahona, C.; Chinsinga, B. Food security, social protection, growth and poverty reduction synergies: The starter pack programme in Malawi. Nat. Resour. Perspect. 2004, 95, 1-6. 
24. Kambewa, P.S.; Mataya, B.F.; Sichinga, W.K.; Johnson, T.R. Charcoal: The Reality-A Study of Charcoal Consumption, Trade and Production in Malawi. In Small and Medium Forestry Enterprise Series No. 21; International Institute for Environment and Development: London, UK, 2007.

25. National Statistical Office. Malawi Population Census; Government of Malawi: Zomba, Malawi, 1998.

26. Pennise, D.M.; Smith, K.R.; Kithinji, J.P.; Rezende, M.E.; Raad, T.J.; Zhang, J.; Chengwei, F. Emissions of greenhouse gases and other airborne pollutants from charcoal making in Kenya and Brazil. J. Geophys. Res. 2001, 106, 24143-24155.

27. Emrich, W. Handbook of Charcoal Making: The Traditional and Industrial Methods; Springer: Dordrecht, The Netherlands, 1985.

28. Munthali, K.G. Modelling Deforestation in Dzalanyama Forest Reserve, Lilongwe, Malawi: Using Multi-Agent Simulation Approach. Ph.D. Thesis, University of Tsukuba, Tsukuba, Japan, 2013.

(C) 2013 by the authors; licensee MDPI, Basel, Switzerland. This article is an open access article distributed under the terms and conditions of the Creative Commons Attribution license (http://creativecommons.org/licenses/by/3.0/). 